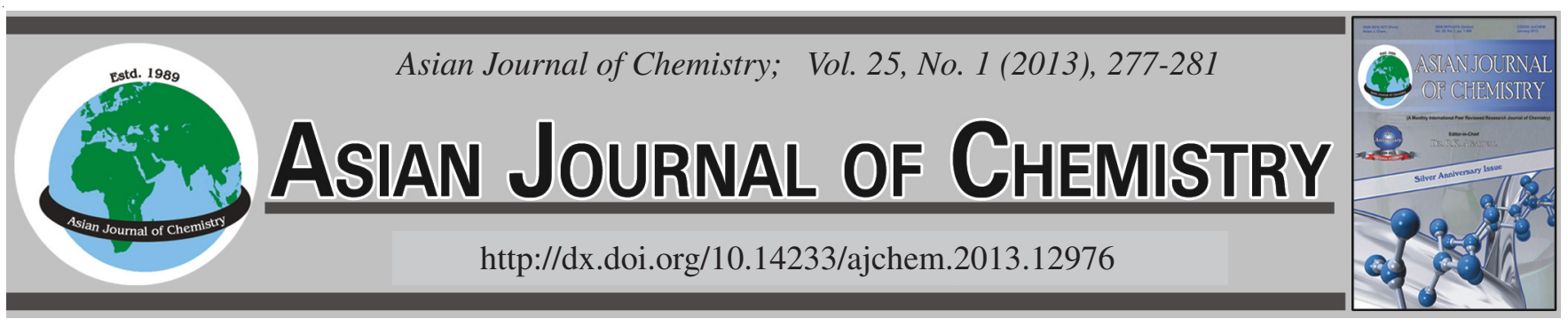

\title{
Synthesis, Spectral Studies and in vitro Antibacterial Evaluation of Triaza and Dioxa Aza Spiro Derivatives
}

Manivannan Natarajan ${ }^{1, *}$, Elanchezhian Balachandravinayagam ${ }^{1}$, Meenakshi Selvaraju $^{2}$ and Selvanathan Ganesan ${ }^{1}$

${ }^{1}$ Department of Chemistry, A.V.C. College (Autonomous), Mannampandal, Mayiladuthurai-6093 05, India

${ }^{2} \mathrm{CAS}$ in Marine Biology, Annamalai University, Parangipettai-608 205, India

*Corresponding author: E-mail: nmrmani@gmail.com

(Received: 31 October 2011;

Accepted: 20 July 2012)

AJC-11862

Six compounds 7,9-diphenyl-1,4-dioxa-8-azaspiro[4.5]decane 1-6 have been synthesized by Mannich reaction and cyclo condensation. |
The structures and stereochemistry established by IR, NMR studies. The purities were checked by elemental analysis. The synthesized
compounds 1-6 adopt chair conformation with equatorial orientation of the aryl groups. All the compounds were screened for their
antibacterial activity against Proteus mirabilis, Klebsiella oxytoca, Staphylococcus aureus and Salmonella paratyphi. The compound 5
exhibited excellent in vitro antibacterial activity in all species.
Key Words: Triaza, Dioxa aza, Spiro, Chair conformation, Antibacterial.

\section{INTRODUCTION}

The Spiro cyclic systems containing one carbon atom common to two rings are structurally exciting ${ }^{1}$. The asymmetric point of the molecule due to the chiral spiro carbon is one of the important criterions of the biological activities. The occurrence of the spiro structure in various natural products also investigated in spiro compounds ${ }^{2}$. Spiro compounds are highly pronounced biological properties ${ }^{3}$. A lot of synthetic methodologies have been developed for constructing these spiro cycles; most of them prefer cyclo addition or condensation reactions $^{4-6}$.

The triaza and dioxa aza spiro compounds are adopt the chair conformation form with equatorial orientation of greater part of the substituents in six membered cyclic compounds. The conformational studies of piperidine have been evaluated by NMR studies ${ }^{7,8}$. All the compounds are screened for their antibacterial activity against Proteus mirabilis, Klebsiella oxytoca, Staphylococcus aureus and Salmonella paratyphi. Imidazolidines and dioxolanes are formed by the reaction of a 1,4-binucleophile with a 1,1-bielectrophile would lead to a five-membered heterocyclic with two hetero atom at 1 and 3 position $^{9,10}$. The examples of commonly encountered 1,4binucleophilies and 1,1-bielectrophiles given in Table-1.

\section{EXPERIMENTAL}

Acetone, ethyl methyl ketone, ammonium acetate, benzaldehyde and solvents were purchased from Sigma-
Aldrich and were used as such. All the reagents and solvents were of laboratory grade.

\begin{tabular}{ll}
\multicolumn{2}{c}{ TABLE-1 } \\
\multicolumn{1}{c}{ 1,4-BINUCLEOPHILIES AND 1,1-BIELECTROPHILES } \\
\hline $\mathrm{H}_{2} \mathrm{~N}-\left(\mathrm{CH}_{2}\right)_{2} \mathrm{NH}_{2}$ & RCOR' \\
$\mathrm{HS}-\left(\mathrm{CH}_{2}\right)_{2} \mathrm{SH}$ & RCHO \\
$\mathrm{H}_{2} \mathrm{~N}\left(\mathrm{CH}_{2}\right)_{2} \mathrm{OH}$ & Carboxylic acid chlorides \\
$\mathrm{H}_{2} \mathrm{~N}\left(\mathrm{CH}_{2}\right)_{2} \mathrm{SH}$ & Phosgene \\
$\mathrm{HS}\left(\mathrm{CH}_{2}\right)_{2} \mathrm{OH}$ & Thiophosgene \\
$o$-Phenyl diamine & ortho-Esters \\
\hline
\end{tabular}

The melting points were determined in open capillaries and are uncorrected. IR spectra were recorded on an AVATAR 330 FT-IR Thermo Nicolet spectrometer in $\mathrm{KBr}$ pellets. Elemental analysis was performed on an Elemental Vario EL III $(\mathrm{C}, \mathrm{H}, \mathrm{N}, \mathrm{O}$ and $\mathrm{Cl})$ analyzer. The purity of the compounds was checked by thin layer chromatography (TLC) with silica gel plates. ${ }^{1} \mathrm{H}$ NMR spectra were recorded on a Bruker AMX300 NMR spectrometer operating at $300.03 \mathrm{MHz}$ for ${ }^{1} \mathrm{H}$ with the following spectral parameters; acquisition time = around $3.0 \mathrm{~s}$, number of scans $=100$ and spectral width $=10,330 \mathrm{~Hz}$. Proton decoupled ${ }^{13} \mathrm{C}$ NMR spectra were recorded on a Bruker AMX-300 NMR spectrometer operating at 75.07 MHz for ${ }^{13} \mathrm{C}$ with the following spectral parameters; acquisition time $=$ around $0.5 \mathrm{~s}$; number of scans $=1000$; spectral width $=30,000$ $\mathrm{Hz}$. All NMR measurements were made in $5 \mathrm{~mm}$ NMR tubes using solutions made by dissolving about $10 \mathrm{mg}$ of the material in $0.5 \mathrm{~mL}$ of DMSO- $d_{6}$. 
Antibacterial activity: The target compounds are screened $^{11}$ against, Proteus mirabilis, Klebsiella oxytoca, Staphylococcus aureus and Salmonella paratyphi. Using the paper disc assay method, Whatman No.1 filter paper disc of $6 \mathrm{~mm}$ diameter was sterilized by autoclaving for $15 \mathrm{~min}$ at $121{ }^{\circ} \mathrm{C}$. The sterile discs were impregnated with different extracts $(1 \mathrm{mg} / \mathrm{mL})$. Agar plates were surface inoculated uniformly from the broth culture of the tested microorganisms. In all cases, the concentration was approximately $1.2108 \mathrm{CFU} /$ $\mathrm{mL}$. The impregnated discs were placed on the medium suitably spaced apart and the plates were incubated at $37^{\circ} \mathrm{C}$ for $24 \mathrm{~h}$. Streptomycin disc was used as a positive control. The diameter $(\mathrm{mm})$ of the growth inhibition halos caused by the compounds was examined.

Preparation of compounds: Piperidin-4-ones (a-d) is prepared by the following procedure of Noller and Baliah ${ }^{12,13}$.

The target spiro compounds 1-6 are prepared by the procedure $^{14,15}$.

Preparation of compounds 1, 2, 4 and 6: A mixture of ethane-1,2-diol and piperidine-4-ones (a,b,c,d) and benzene $(45 \mathrm{~mL})$ on round bottom flask. The reaction flask is fixed with a Dean-stark water separator and charged with anhydrous $\mathrm{K}_{2} \mathrm{CO}_{3}$. The solution is quietly refluxed for $14 \mathrm{~h}$ and cooled in the room temperature and a yellow oily solution is obtained and later petroleum-ether $\left(60-80^{\circ} \mathrm{C}\right)$ was added. The product is separated as pale yellow solid. This similar way follows for preparation of compounds 1, 2, 4 and 6.

Preparation of compounds 3 and 5: A mixture of ethane1,2-diamine and piperidine-4-one (c, $\mathbf{d})$ and benzene $(45 \mathrm{~mL})$ placed in a round bottom flask. The reaction flask is fixed with a Dean-stark water separator and charged with anhydrous $\mathrm{K}_{2} \mathrm{CO}_{3}$. The solution is quietly refluxed for $14 \mathrm{~h}$ and cooled in the room temperature and a yellow oily solution is obtained and later petroleum-ether $\left(60-80^{\circ} \mathrm{C}\right)$ was added. The product is separated as pale yellow solid. This method follows compounds $\mathbf{3}$ and $\mathbf{5}$.

\section{RESULTS AND DISCUSSION}

Synthesis of the compounds and the numbering of atoms: Compounds 7,9-diphenyl-1,4-dioxa-8-aza spiro[4.5] decane, 6-methyl-7,9-diphenyl-1,4-dioxa-8-aza spiro[4.5] decane, 7,9-bis-(4-chlorophenyl)-6-methyl-1,4,8-triaza spiro [4.5]decane, 7,9-bis-(4-chlorophenyl)-6-methyl-1,4 -dioxa-8aza spiro[4.5]decane,7,9-bis-(4-methoxyphenyl)-6-methyl1,4,8-triazaspiro[4.5]decane and 7,9-bis-(4-methoxyphenyl)-6methyl-1,4,-dioxa-8-aza spiro[4.5]decane 1-6 have been synthesized by using reactions shown in Scheme-I. The numbering of carbon atoms is shown in Fig. 1. The methylene protons in the cyclohexane ring are denoted as axial and equatorial protons assuming chair conformation for the cyclohexane ring.<smiles>[Y]C1C([Al])NC([Tl])CC12[Y]CCO2</smiles>

$\mathbf{x}$
$\mathrm{O}$
$\mathrm{O}$
$\mathrm{NH}$
$\mathrm{O}$
$\mathrm{NH}$
$\mathrm{O}$

Fig. 1.
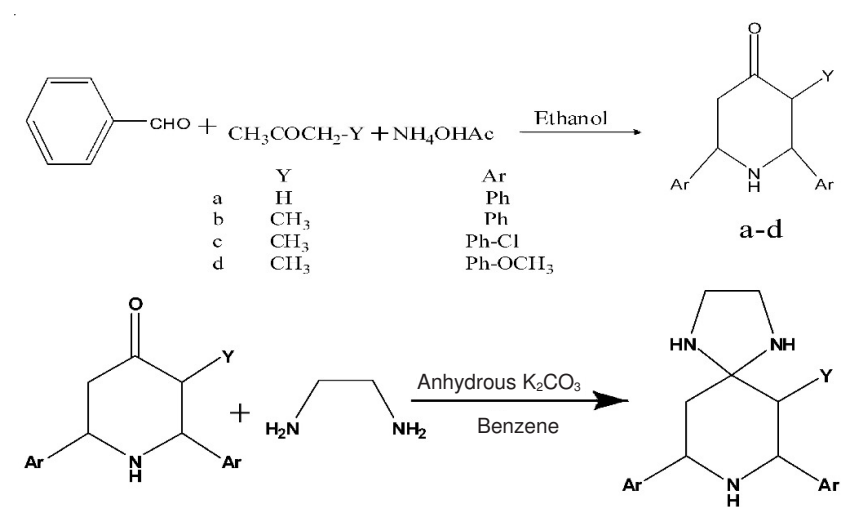

$\mathrm{Y}=\mathrm{CH}_{3}, \quad \mathrm{Ar}=p$-chlorophenyl, $p$-methoxy phenyl<smiles>[Y]C1CC(=O)C([Y])C([Y])N1</smiles>

$\mathrm{Y}=\mathrm{H}, \mathrm{CH}_{3} \mathrm{Ar}=$ Phenyl, $p$-Cl-Phenyl, p-methoxy-Phenyl Scheme-I

The conformation and optimization of the target compounds structure shown that the atoms or group of atoms are arranged in molecule with reference to space. The optimization structures of favoured conformations 1-6 are given in Fig. 2.

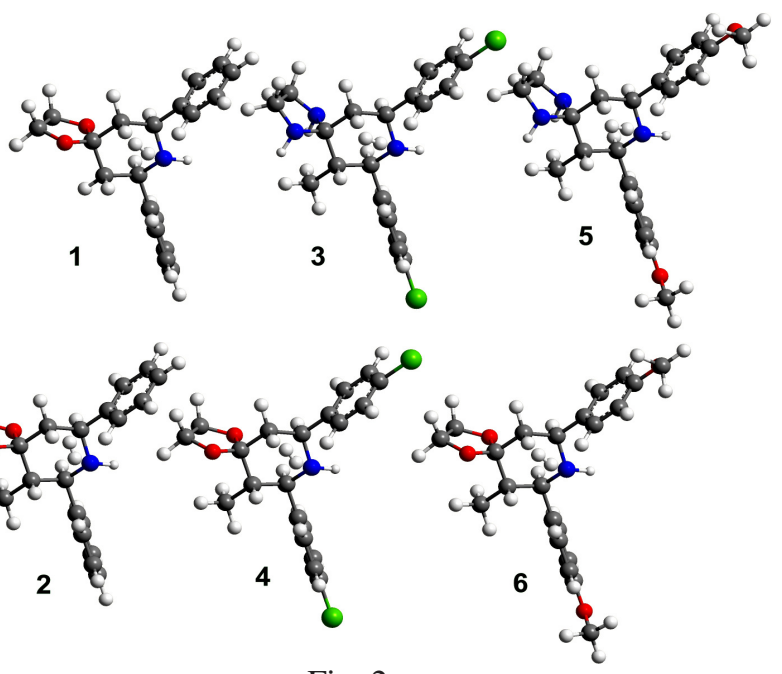

Fig. 2.

Mass-spectra and IR: Physical properties, mass spectral data and IR spectral data's are given in Table- 2 and 3 respectively. In the mass spectra, for all compounds molecular ion peak corresponding to the molecular formula were observed. The carbonyl stretching frequencies of the title compounds are mislaid to compare parent compound a-d. The carbonyl group are involved in condensation reaction with 1,4binucleophilic reactants. The N-H stretching frequencies for the compounds 1-6 were in the range of $3427-3300 \mathrm{~cm}^{-1}$.

Assignments of ${ }^{1} \mathbf{H}$ NMR signals: ${ }^{1} \mathrm{H}$ NMR spectral data's of the products were compared with compounds $\mathbf{7}$ and $\mathbf{8}^{\mathbf{1 6 , 1 7}}$ are listed in Table- 4 . The compounds $\mathbf{7}$ and $\mathbf{8}$ chair conformation 


\begin{tabular}{|c|c|c|c|c|c|c|c|c|}
\hline \multicolumn{9}{|c|}{$\begin{array}{c}\text { TABLE-2 } \\
\text { PHYSICAL PROPERTIES AND MASS SPECTRAL DATA }\end{array}$} \\
\hline \multirow{2}{*}{ Compounds } & \multirow{2}{*}{ m.f. } & \multirow{2}{*}{ m.p. $\left({ }^{\circ} \mathrm{C}\right)$} & \multicolumn{4}{|c|}{ Elemental analysis (\%) } & \multirow{2}{*}{ Yield (\%) } & \multirow{2}{*}{ Mass of parent ion } \\
\hline & & & $\mathrm{H}$ & $\mathrm{C}$ & $\mathrm{N}$ & $\mathrm{Cl}$ & & \\
\hline 1 & $\mathrm{C}_{19} \mathrm{H}_{21} \mathrm{NO}_{2}$ & 96 & 7.17 & 77.26 & 4.74 & - & 70 & 295 \\
\hline 2 & $\mathrm{C}_{20} \mathrm{H}_{23} \mathrm{NO}_{2}$ & 86 & 7.49 & 77.64 & 4.53 & - & 65 & 309 \\
\hline 3 & $\mathrm{C}_{20} \mathrm{H}_{23} \mathrm{~N}_{3} \mathrm{Cl}_{2}$ & 110 & 6.16 & 63.83 & 11.17 & 18.84 & 60 & 377 \\
\hline 4 & $\mathrm{C}_{20} \mathrm{H}_{21} \mathrm{NO}_{2} \mathrm{Cl}_{2}$ & 94 & 5.60 & 63.50 & 3.70 & 18.74 & 60 & 379 \\
\hline 5 & $\mathrm{C}_{22} \mathrm{H}_{29} \mathrm{~N}_{3} \mathrm{O}_{2}$ & 92 & 7.95 & 71.91 & 11.43 & - & 55 & 367 \\
\hline 6 & $\mathrm{C}_{22} \mathrm{H}_{27} \mathrm{NO}_{4}$ & 118 & 7.37 & 71.52 & 3.79 & - & 55 & 369 \\
\hline
\end{tabular}

is given in Fig. 3. The signals in the ${ }^{1} \mathrm{H}$ NMR spectra of 1-6 were assigned based on positions, multiplicities and integral values. The NMR data's of the products shown that the piperidine ring in the molecule favoured chair conformation.

TABLE-3

IR STRETCHING FREQUENCIES $\left(\mathrm{cm}^{-1}\right)$ OF COMPOUNDS 1-6

\begin{tabular}{cccccc}
\hline Comp. & NH & $\begin{array}{c}\text { Aromatic } \\
\text { C-H }\end{array}$ & $\begin{array}{c}\text { Aliphatic } \\
\mathrm{CH}_{3}\end{array}$ & C-O-C & C-N \\
\hline $\mathbf{1}$ & 3300 & 2956 & - & 513 & 1156,1176 \\
$\mathbf{2}$ & 3309 & 3029 & 2929 & 513 & 1138 \\
$\mathbf{3}$ & 3424 & 3010 & 2935 & - & 1112,1143 \\
$\mathbf{4}$ & 3301 & 3027 & 2957 & 1174 & 1143 \\
$\mathbf{5}$ & 3427 & 3022 & 2961 & - & 1142,1112 \\
$\mathbf{6}$ & 3349 & 3015 & 2935 & 1218 & 1143 \\
\hline
\end{tabular}
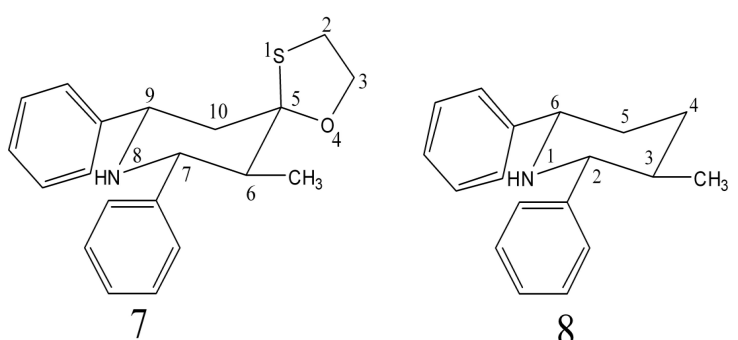

7=6-methyl-,7,9-diphenyl-8-aza-4-oxa-1-thio spiro[4.5]decane $\quad 8=3$-methyl-r(2),c(6)-diphenylpiperidine

Fig. 3.
The various protons coupling constant are given in Table5. The ${ }^{1} \mathrm{H}$ NMR results of synthesized compound 1-6 were compared with reference compound $\mathbf{7}$ and $\mathbf{8}$ shows small variations. The reference compound $7, \mathrm{H}-2$ and $\mathrm{H}-3$ protons are observed down field when compare with synthesized compounds 1-6, due to strong electro negativity of sulphur than nitrogen and oxygen.

Analysis of coupling constant: For 1 observed one large vicinal coupling constant between $\mathrm{H}(6 \mathrm{a})$ and $\mathrm{H}(7 \mathrm{a})$ or $\mathrm{H}(9 \mathrm{a})$ and $\mathrm{H}(10 \mathrm{a})$ is found as $10.2 \mathrm{~Hz}$ and one small coupling $\mathrm{H}(6 \mathrm{e})$ and $\mathrm{H}(7 \mathrm{a})$ or $\mathrm{H}(9 \mathrm{a})$ and $\mathrm{H}(10 \mathrm{e})$ is found as $3.9 \mathrm{~Hz}$. The geminal coupling constant $\mathrm{H}(10 \mathrm{a}) \mathrm{H}(10 \mathrm{e})$ is found as $15.6 \mathrm{~Hz}$. For 2-6, $\mathrm{H}(6 \mathrm{a})$ and methyl coupling constant were found as $6.6 \mathrm{~Hz}$. Vicinal(axial-axial) coupling constant between $\mathrm{H}(7 \mathrm{a})$ and $\mathrm{H}(6 \mathrm{a})$ were found as $11.4,10.5,10.5,10.2$ and $7.2 \mathrm{~Hz}$, another one found in $\mathrm{H}(9 \mathrm{a})$ and $\mathrm{H}(10 \mathrm{a})$ were $10.5,12.3,8.4$ and 8.7 $\mathrm{Hz}$ respectively. The vicinal (axial-equatorial) coupling constant between $\mathrm{H}$ (9a) and $\mathrm{H}$ (10e) were found 3.9, 3.3, 3.0 and $2.7 \mathrm{~Hz}$ and the geminal coupling constant between $\mathrm{H}(10 \mathrm{a})$ and $\mathrm{H}(10 \mathrm{e})$ were found as $7.2,12.0$ and $13.5 \mathrm{~Hz}$. The favoured chair conformation structures are given in Fig. 4.

Assignments of ${ }^{13} \mathbf{C}$ NMR signals: The proton- decoupled ${ }^{13} \mathrm{C}$ NMR spectral data of the products were compared with reference compounds $\mathbf{7}$ and $\mathbf{8}$ are given in Table- 6 . The aromatic carbons could be readily distinguished by their characteristic absorption above $100 \mathrm{ppm}$. Assignments for the benzylic

TABLE-4

PROTON CHEMICAL SHIFTS OF 1-6 AND REFERENCE COMPOUND 7, 8

\begin{tabular}{|c|c|c|c|c|c|c|c|c|c|c|}
\hline \multirow{2}{*}{ Compounds } & \multicolumn{10}{|c|}{ Chemical shifts, $\delta(\mathrm{ppm})$} \\
\hline & $\mathrm{H}-7 \mathrm{a}$ & H-9a & H-6a & $\mathrm{H}-10 \mathrm{a}$ & $\mathrm{H}-10 \mathrm{e}$ & Aromatic & $\mathrm{NH}$ & $\mathrm{C} 2-\mathrm{C} 3$ & $\mathrm{CH}_{3}$ & $\mathrm{OCH}_{3}$ \\
\hline 1 & 4.06 & & 1.95 & & & $7.25-7.48$ & 1.60 & $3.25-3.37$ & - & - \\
\hline 2 & 4.07 & 3.5 & 2.02 & 1.85 & & $7.2-7.4$ & 1.70 & $3.2-3.4$ & 0.81 & - \\
\hline 3 & 3.58 & 4.03 & 2.54 & 1.90 & & $7.29-7.42$ & 1.80 & $2.93-3.38$ & 0.82 & - \\
\hline 4 & 3.60 & 4.04 & 2.59 & 1.922 & & $7.26-7.42$ & 1.75 & $3.10-3.30$ & 0.81 & - \\
\hline 5 & 3.53 & 3.99 & 2.60 & 2.06 & 2.18 & $6.85-7.37$ & 1.65 & $2.92-3.24$ & 0.82 & 3.78 \\
\hline 6 & 3.70 & 4.00 & 2.65 & 1.95 & 2.09 & $6.83-7.35$ & 1.75 & $3.2-3.64$ & 0.81 & 3.78 \\
\hline 7 & 3.80 & 4.14 & 2.07 & 2.07 & 2.40 & - & 1.76 & $2.99-4.06$ & 0.80 & - \\
\hline 8 & - & $\mathrm{H}_{2 \mathrm{a}-} 3.34$ & 3.80 & - & - & - & & & & \\
\hline
\end{tabular}

TABLE-5

PROTON-PROTON COUPLING CONSTANTS IN 1-6

\begin{tabular}{|c|c|c|c|c|c|c|c|}
\hline \multirow{2}{*}{ Compounds } & \multicolumn{7}{|c|}{ Coupling constants $(\mathrm{Hz})$} \\
\hline & $\mathrm{3}_{\mathrm{CH}, 6 \mathrm{a}}$ & ${ }^{3} \mathrm{~J}_{7 \mathrm{a}, 6 \mathrm{a}}$ & ${ }^{3} J_{9 a, 10 a}$ & ${ }^{3} J_{9 \mathrm{a}, 10 \mathrm{e}}$ & ${ }^{2} J_{10 a, 10 e}$ & ${ }^{3} \mathbf{J}_{6 \mathrm{a}, 7 \mathrm{a}}$ or ${ }^{3} \mathbf{J}_{10 \mathrm{a}, 9 \mathrm{a}}{ }^{*}$ & ${ }^{3} \mathbf{J}_{6 \mathrm{e}, 7 \mathrm{a}}$ or ${ }^{3} \mathbf{J}_{10 \mathrm{e}, 9 \mathrm{a}}{ }^{*}$ \\
\hline 1 & - & - & - & - & 15.6 & 10.2 & 3.9 \\
\hline 2 & 6.6 & 11.4 & 10.5 & 3.9 & 7.2 & - & - \\
\hline 3 & 6.6 & 10.5 & 12.3 & - & - & - & - \\
\hline 4 & 6.6 & 10.5 & - & 3.3 & - & - & - \\
\hline 5 & 6.6 & 10.2 & 8.4 & 3.0 & 12.0 & - & - \\
\hline 6 & 6.6 & 7.2 & 8.7 & 2.7 & 13.5 & - & - \\
\hline
\end{tabular}


<smiles></smiles><smiles>CC1CCC2(C1)C[C@H]2c1ccccc1</smiles>

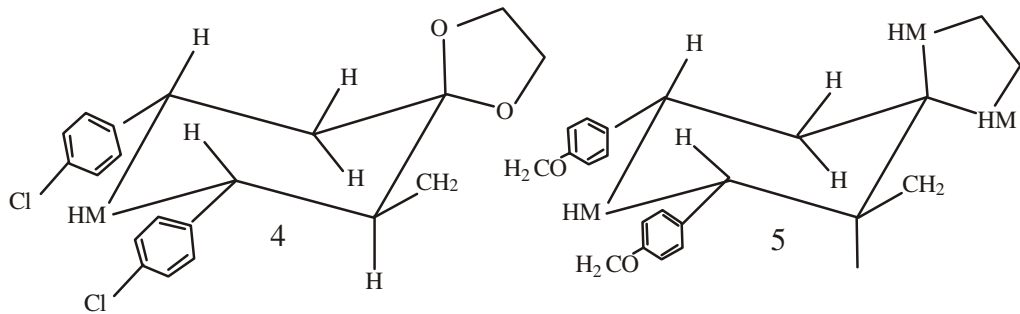

Fig. 4.<smiles>CC(Cc1ccc(Cl)cc1)CC1NCCC1C</smiles><smiles>COc1ccc(C2NCCC3CCCCC32)cc1</smiles>

TABLE-6

${ }^{13} \mathrm{C}$ CHEMICAL SHIFTS OF COMPOUNDS 1-6 AND REFERENCE COMPOUNDS 7,8

\begin{tabular}{ccccccccccccc}
\hline Comp. & $\mathrm{C}(5)$ & $\mathrm{C}(7)$ & $\mathrm{C}(9)$ & $\mathrm{C}(6)$ & $\mathrm{C}(10)$ & $\mathrm{C}(3)$ & $\mathrm{C}(2)$ & $\begin{array}{c}\text { Aromatic } \\
\text { carbons }\end{array}$ & $\begin{array}{c}\mathrm{Ph}-\mathrm{ipso} \\
\text { carbons }\end{array}$ & $\mathrm{Ph}-\mathrm{Cl} / \mathrm{Ph}-\mathrm{CH}_{3}$ & $\mathrm{CH}_{3}$ & $\mathrm{OCH}_{3}$ \\
\hline 1 & 86.05 & \multicolumn{2}{c}{61.22} & \multicolumn{2}{c}{50.39} & 51.13 & 49.04 & $126.5-128.7$ & 142.7 & - & - \\
2 & 93.37 & 68.47 & 61.58 & 45.15 & 47.58 & 51.67 & 50.89 & $126.5-128.6$ & $141.9,142.7$ & - & - \\
3 & 82.57 & 67.67 & 60.88 & 51.63 & 50.81 & 48.80 & 46.88 & $127.8-129.0$ & $133.5,133.7$ & $140.26,141.23$. & 10.07 & - \\
4 & 89.02 & 67.70 & 60.90 & 51.65 & 48.95 & 54.62 & 48.95 & $127.8-129.0$ & $133.6,133.8$ & $140.26,141.13$. & 10.08 \\
5 & 84.89 & 67.89 & 61.00 & 46.85 & 45.07 & 43.85 & 42.09 & $113.8-128.7$ & $134.2,135.1$ & $159.15,159.27$. & 10.17 & 55.28 \\
6 & 94.85 & 67.90 & 61.01 & 49.03 & 48.64 & 51.85 & 51.07 & $113.8-128.7$ & $134.2,135.1$ & $159.16,159.28$. & 10.18 & 55.29 \\
7 & 96.92 & 65.67 & 58.64 & 49.22 & 46.88 & 33.89 & 71.39 & - & - & - & 11.70 & - \\
8 & 35.0 & $\mathrm{C}(2)$ & $\mathrm{C}(6)$ & $\mathrm{C}(3)$ & $\mathrm{C}(5)$ & - & - & - & - & - & 18.7 \\
\hline
\end{tabular}

carbons have been made on the basis of known effects of alkyl substituents in six-membered ring compounds. The decoupled carbon NMR values observed for spiro ipso carbon $\mathrm{C}(5)$ are $86.05,93.37,82.57,89.02,84.89$ and 94.85 ppm respectively. These values point out the neighboring atoms. The compounds $\mathbf{3}$ and $\mathbf{5}$ having lower chemical shift when compare with 1, 2, 4 and $\mathbf{6}$ value, due to nitrogen having lower electro negativity than oxygen at 1,3 position.

These values point out the neighboring atoms. The compounds $\mathbf{3}$ and $\mathbf{5}$ having lower chemical shift when compare with 1, 2, 4 and 6 value, due to nitrogen having lower electro negativity than oxygen at 1,3 position. The benzylic carbons signals $\mathrm{C}(7)$ appears at down field to compare $\mathrm{C}(9)$ and $\mathrm{C}(6)$ appear at down field to compare $\mathrm{C}(10)$ due to the deshielding factor. The $\mathrm{OCH}_{3}$ appears down field to compare $\mathrm{CH}_{3}$ due to the more electronegative nature of methoxy. The aromatic carbons are observed around 110-130 ppm, phenyl ipso carbons observed at 142.7, 141.9, 142.7, 133.5, 133.7, 133.6, $133.8,134.2,135.1$ and 134.2, $135.1 \mathrm{ppm}$ in that order. The chloro phenyl and metonymy phenyl ipso carbons are found at $140.26,141.23,140.26,141.13,159.15,159.27,159.16$, $159.28 \mathrm{ppm}$ in that order.

${ }^{13} \mathrm{C}$ NMR results of compounds $\mathbf{1 - 8}, \mathrm{C}(5)$ observed on up field in $\mathbf{8}$ because there is no electronegative atoms in nearest position, but in 7 observed down field to compare 1-6 because the sulphur atom present in the molecule. The $\mathrm{C}(2), \mathrm{C}(3)$ were observed up field, down field respectively in 7, but 1-6 observed in between the above range due to the nitrogen and oxygen.
Antibacterial activity: For evaluating antibacterial activity streptomycin was used as the standard drug. The observed minimum inhibitory concentrations (MIC) are given in Table-7.

TABLE-7

ANTIBACTERIAL ACTIVITY OF COMPOUNDS 1-6

\begin{tabular}{ccccc}
\hline \multirow{2}{*}{ Compound } & \multicolumn{4}{c}{ Minimum inhibitory concentration $\left(\mu \mathrm{gL}^{-1}\right)$} \\
\cline { 2 - 5 } & $\begin{array}{c}\text { Proteous } \\
\text { mirabilis }\end{array}$ & $\begin{array}{c}\text { Klebsiella } \\
\text { oxytoca }\end{array}$ & $\begin{array}{c}\text { Staphylococcus } \\
\text { aurous }\end{array}$ & $\begin{array}{c}\text { Salmonella } \\
\text { paratyphoid }\end{array}$ \\
\hline $\mathbf{1}$ & - & 6.6 & - & 8.1 \\
$\mathbf{2}$ & - & - & 9 & - \\
$\mathbf{3}$ & 6.3 & - & 6.1 & 6.5 \\
$\mathbf{4}$ & - & - & 5.5 & - \\
$\mathbf{5}$ & 8.2 & 7.8 & 8.7 & 7.9 \\
$\mathbf{6}$ & 7.6 & 8.4 & 7.0 & - \\
$\mathbf{7}$ & 5.5 & 5.5 & 6.0 & 6.0 \\
\hline Streptomycin] & 5.5 & & & \\
\hline
\end{tabular}

All the compounds were screened for their antibacterial activity against some significant bacterial species are Proteus mirabilis, Klebsiella oxytoca, Staphylococcus aureus and Salmonella paratyphi. Compounds 1-6 with various substituents in the aromatic ring will be useful in understanding the influence of steric and electronic effects on the biological activity. The plot diagram of compounds 1-6 are comparing with streptomycin 7. The replacement of carbon by nitrogen and oxygen to increase the biological activity. The proportional antibacterial evaluations are given in bar diagram in Fig. 5. 


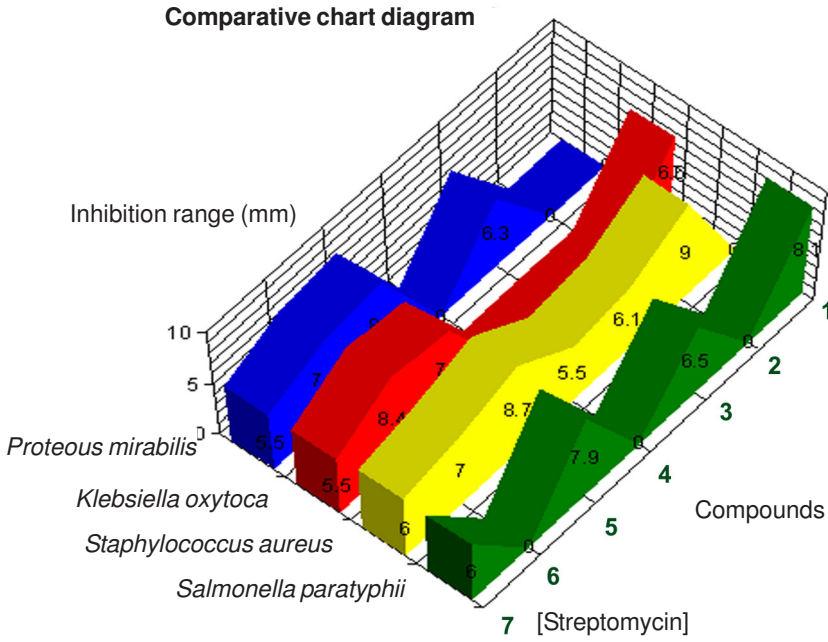

Fig. 5.

\section{Conclusion}

A series of compounds 1-6 were synthesized and screened for their antibacterial activity. The observed vicinal protonproton coupling and geminal coupling constants suggest that in 1-6 piperidine rings adopts chair conformation with equatorial orientations of the aryl groups. The compound $\mathbf{5}$ has high antibacterial activity against the bacterial species compared with norfloxacin standard compound. The spiro products (1-6) are highly active against Staphylococcus aureus.

\section{ACKNOWLEDGEMENTS}

The authors are thankful to Dr. K. Pandiarajan, Department of Chemistry, Annamalai University, Chidambaram and Indian Institute of Technology Madras for providing spectral data.

\section{REFERENCES}

1. M. Sannigrahi, Tetrahedron, 55, 9007 (1999).

2. N. Srivastav, A. Mittal and A. Kumar, J. Chem. Soc., 35, 493 (1992).

3. D.M. James, H.B. Kunze and D.J. Faulkner, J. Nat. Prod., 54, 1137 (1991).

4. M. Jambuligam, A. Sathish, J. Vasanthakumar and K. Rakkiyappan, Asian J. Chem., 16, 1261 (2004).

5. C. Marti and E.M. Carreira, J. Am. Chem. Soc., 127, 1150 (2005)

6. R. Thilakam, V. Jayamani, A.K. Gayathiri and R. Kalpana, Asian J. Chem., 23, 4268 (2011).

7. M.U. Hasan, M. Arab, K. Pandiarajan, R. Sekar and D. Marko, Mag. Res. Chem., 23, 292 (1985).

8. K. Pandiarajan, R.T. Sabapathymohan and M.U. Hasan, Mag. Res. Chem., 24, 312 (1986).

9. T. Ravindran and R. Jeyaraman, Indian J. Chem., 31B, 677 (1992).

10. V.V. Dhabokar and M.W. Mihiradkar, Indian J. Chem., 48B, 1027 (2009).

11. H.A. El-Masry, H.H. Fahmy and A.S.H. Abdelwahed, Molecules, 5, 1429 (2000).

12. V. Baliah, A. Ekambaram and T.S. Govindarajan, Curr. Sci., 23, 264 (1954).

13. O.R. Noller and V. Baliah, J. Am. Chem. Soc., 70, 3853 (1948).

14. N. Pathmavathi, A. Baliah and B. Reddy, Indian J. Chem., 41B, 1670 (2002).

15. N. Pathmavathi, A. Baliah and T.V.R. Reddy, B.J. Reddy and D.B. Reddy, Heteroatom Chem., 14, 513 (2003).

16. M. Sujatha and R. Jeyaraman, Indian J. Chem., 31B, 507 (1992).

17. T. Ravindran and R. Jeyaraman, Indian J. Chem., 31B, 677 (1992). 